\title{
Seismic Sources on the Iberia-African Plate Boundary and their Tectonic Implications
}

\author{
E. Buforn ${ }^{1}$, M. Bezzeghoud ${ }^{2}$, A. Udías ${ }^{1}$, and C. Pro $^{3}$
}

\begin{abstract}
The plate boundary between Iberia and Africa has been studied using data on seismicity and focal mechanisms. The region has been divided into three areas: A; the Gulf of Cadiz; B, the Betics, Alboran Sea and northern Morocco; and C, Algeria. Seismicity shows a complex behavior, large shallow earthquakes $(\mathrm{h}<30 \mathrm{~km})$ occur in areas $\mathrm{A}$ and $\mathrm{C}$ and moderate shocks in area $\mathrm{B}$; intermediate-depth activity $(30<\mathrm{h}<150 \mathrm{~km})$ is located in area $\mathrm{B}$; the depth earthquakes $(\mathrm{h} \approx 650 \mathrm{~km})$ are located to the south of Granada. Moment rate, slip velocity and $b$ values have been estimated for shallow shocks, and show similar characteristics for the Gulf of Cadiz and Algeria, and quite different ones for the central region. Focal mechanisms of 80 selected shallow earthquakes $\left(8 \geq m_{b} \geq 4\right)$ show thrust faulting in the Gulf of Cadiz and Algeria with horizontal NNW-SSE compression, and normal faulting in the Alboran Sea with E-W extension. Focal mechanisms of 26 intermediate-depth earthquakes in the Alboran Sea display vertical motions, with a predominant plane trending E-W. Solutions for very deep shocks correspond to vertical dip-slip along N-S trends. Frohlich diagrams and seismic moment tensors show different behavior in the Gulf of Cadiz, Betic-Alboran Sea and northern Morocco, and northern Algeria for shallow events. The stress pattern of intermediate-depth and very deep earthquakes has different directions: vertical extension in the NW-SE direction for intermediate depth earthquakes, and tension and pressure axes dipping about $45^{\circ}$ for very deep earthquakes. Regional stress pattern may result from the collision between the African plate and Iberia, with extension and subduction of lithospheric material in the Alboran Sea at intermediate depth. The very deep seismicity may be correlated with older subduction processes.
\end{abstract}

Key words: Plate boundary, Iberia-African, seismicity, focal mechanisms, intermediate and deep depth earthquakes, subduction.

\section{Introduction}

The interaction between Iberia and Africa results in a complex region located in the western part of the Eurasian-African plate boundary. This region corresponds to the transition from an oceanic boundary (between the Azores and the Gorringe Bank), to a continental boundary where Iberia and Africa meet. The plate boundary is very well delimited in the oceanic part, from the Azores Islands along the AzoresGibraltar fault to approximately $12^{\circ} \mathrm{W}$ (west of the Strait of Gibraltar). From $12^{\circ} \mathrm{W}$

\footnotetext{
${ }^{1}$ Dpt. de Geofísica, Universidad Complutense, Madrid, Spain.

${ }^{2}$ Dpt. de Física. Universidade de Evora and CGE, Evora, Portugal.

${ }^{3}$ Dpt. de Física, Universidad de Extremadura, Spain.
} 


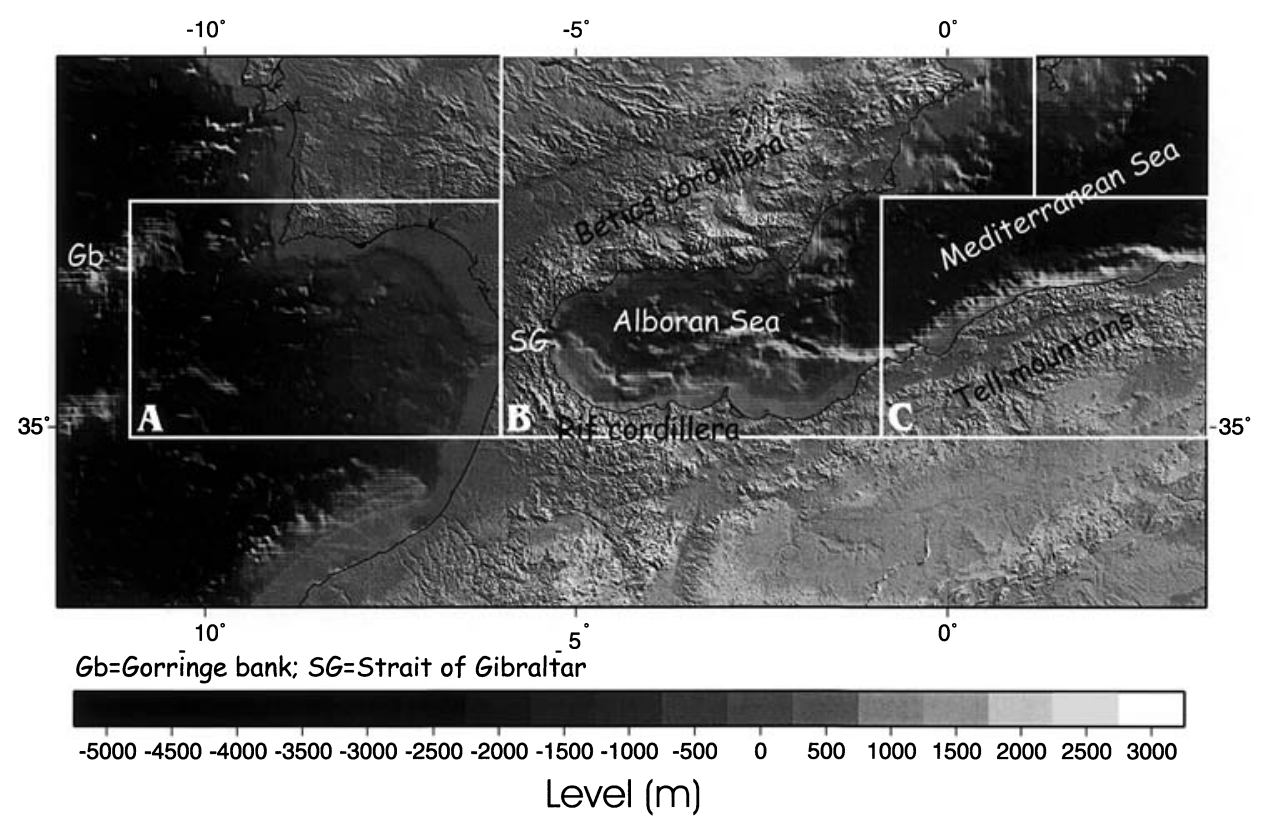

Figure 1

Topography and bathymetry of the Iberia-African region.

to $3.5^{\circ} \mathrm{E}$, including the Iberia-African region and extending to the western part of Algeria, the boundary is more diffuse and forms a wider area of deformation (Buforn et al., 1988a; Morel and Meghraoui, 1996; Hayward et al., 1999).

The complexity of the region is reflected in its bathymetry, seismicity, stress regime and tectonics. In Figure 1 bathymetry and topography for this region are shown. On land, the main geological features are the Betics, the Rif Cordilleras and the Tell Mountains, formed basically by the Alpine domain, a consequence of the collision between Eurasia and Africa. The bathymetry shows, as main features, the Gorringe Bank region, located west of the Strait of Gibraltar, with a number of seamounts, banks and submarine ridges, and the Alboran Sea east of the Strait of Gibraltar, with important regional crustal thickness variations (TORNÉ et al., 2000).

Plate kinematic models for the region have estimated convergence rates of $4 \mathrm{~mm} /$ yr at the Gorringe Bank and Gibraltar, and $6 \mathrm{~mm} / \mathrm{yr}$ in the Algerian region (ARGUS et al., 1989; DeMets et al., 1990), and $7.6 \mathrm{~mm} / \mathrm{yr}$ in northwestern Algeria from seismic slip rate (LAmMALI et al., 1997). From west to east along the plate boundary between Eurasia and Africa, the general stress pattern corresponds to extension in the Azores region, right-lateral strike-slip motion in the central part and compression in the eastern region, from Gorringe Bank to the Strait of Gibraltar and Algeria (McKenzie, 1972; UdíAs et al., 1976; Grimison and Chen, 1986; Buforn et al., 1988a; JimenEZ-MunT et al., 2001; NEGREDO et al., 2002). 
In this paper we have divided the Iberia-African plate boundary region into three areas: A (Gulf of Cadiz to Gorringe Bank), B (central part including Betic and Rif Cordilleras and the Alboran Sea) and C (northwest Algeria and Tell Mountains). We will examine the different characteristics of these three areas using observations of seismicity and focal mechanisms.

\section{Shallow Earthquakes}

Seismicity of the Iberia-African region is characterized by the occurrence of earthquakes of moderate magnitude, most of them with focus at shallow depth $(0<\mathrm{h}<40 \mathrm{~km})$. The distribution of epicenters corresponding to magnitude $\mathrm{m}_{\mathrm{b}} \geq 3.5$, taken from the Instituto Geográfico Nacional Data File (IGN Data File) for the period 1980-1999, is shown in Figure 2. Magnitudes in the IGN Data File have been determined using $\mathrm{Lg}$ waves adjusted to values of $\mathrm{m}_{\mathrm{b}}$ (BoLETín DE SISMOS Próximos, 1989). Most shocks correspond to shallow events with magnitudes, in general, less than 5.5. For the 1980-1999 time period, only one earthquake has magnitude greater than 6.0 (El Asnam, Algeria, earthquake 10.10.1980; $\mathrm{M}_{\mathrm{s}}=7.3$ ). West of Gibraltar, from the Gulf of Cadiz to the Gorringe bank region (area A), epicenters are distributed in an E-W direction, across a band about 100-km wide, with foci at shallow and intermediate depth (Fig. 2). Before the period represented in Figure 2, two large earthquakes had occurred in this region, one in the Gulf of Cádiz (15.3.1964; $\left.\mathrm{M}_{\mathrm{s}}=6.4\right)$ and another west of the San Vicente Cape (29.2.1969; $\left.\mathrm{M}_{\mathrm{s}}=8\right)$

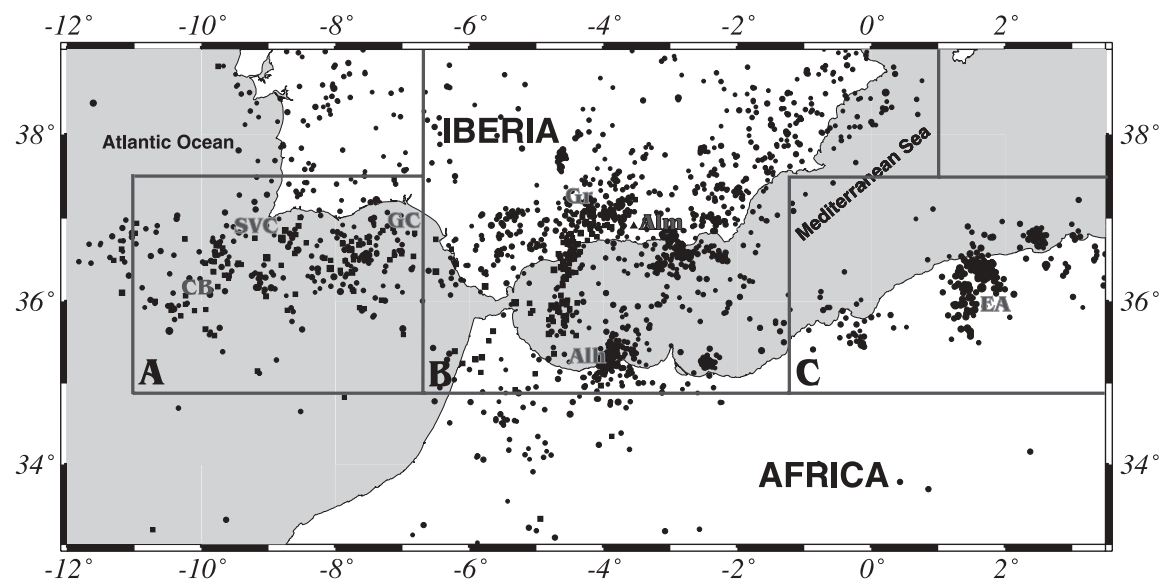

Figure 2

Distribution of epicenters for the period $1980-1999\left(\mathrm{~m}_{\mathrm{b}} \geq 3.5\right)$ taken from the IGN Data File. Circles correspond to shallow earthquakes $(\mathrm{h}<40 \mathrm{~km})$, squares to intermediate depth $(40<\mathrm{h}<150 \mathrm{~km})$ and triangles to very deep $(\mathrm{h}>600 \mathrm{~km})$. $\mathrm{GB}=$ Gorringe Bank, SVC $=$ San Vicente Cape, GC $=\mathrm{Gulf}$ of Cádiz, $\mathrm{Gr}=$ Granada, Alm = Almería, ALH = Alhoceima; EA = El Asnam. 


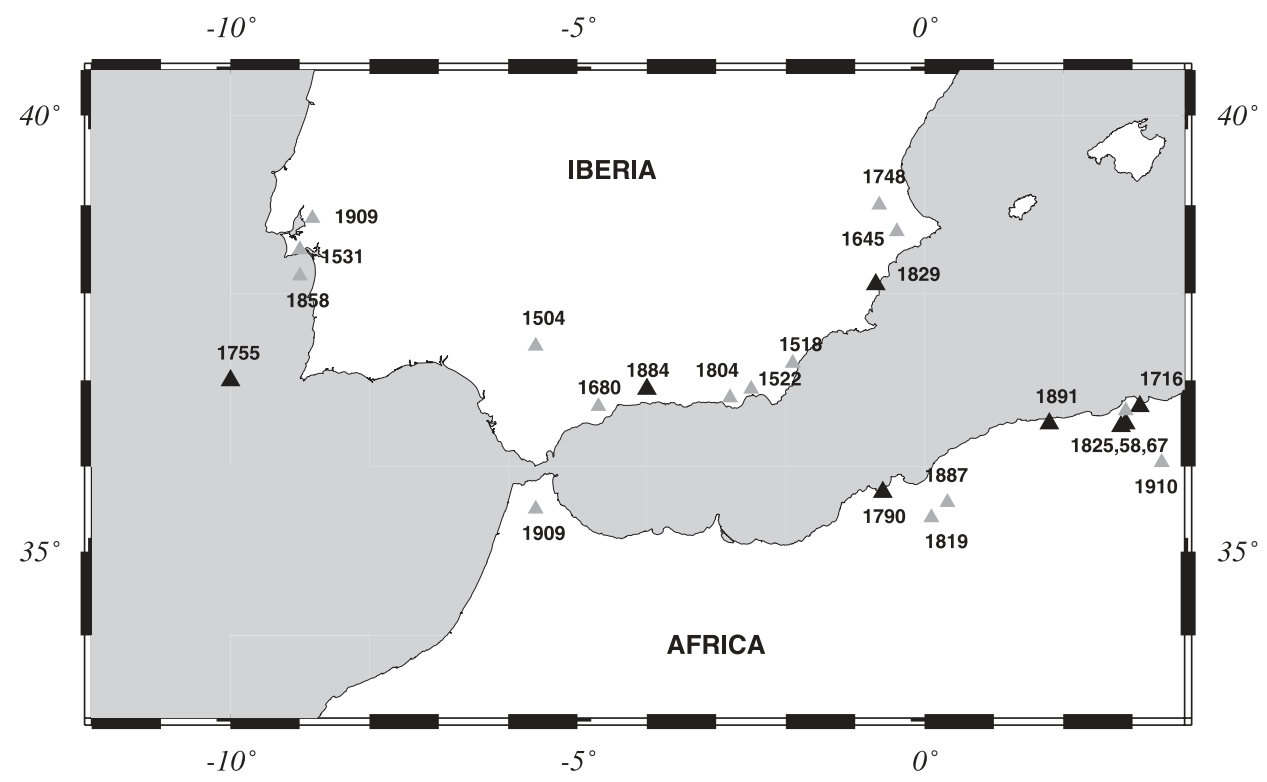

Figure 3

Historical seismicity for the studied region. In black earthquakes with maximum intensity $=\mathrm{X}$, in grey maximum intensity $=$ IX.

(UdíAs et al., 1976; BUFORN et al., 1988b). In area B there are three main concentrations of epicenters, at $4^{\circ} \mathrm{W}$ (the Alhoceima region, northern Morocco), where in 1994 an earthquake of magnitude $\mathbf{M}_{\mathrm{w}}=5.8$ occurred (CALVERT et al., 1997; Bezzeghoud and Buforn, 1999); at $2.5^{\circ} \mathrm{W}$ in the Almeria region (SE Spain) where a swarm occurred in 1993-1994 with two shocks of magnitudes 5.0 (RUEDA et al., 1996), and at $4.5^{\circ} \mathrm{W}$ in the Granada Basin with frequent shocks of $\mathrm{m}_{\mathrm{b}}$ about 3 . In area $\mathrm{C}$ shocks are concentrated in the $\mathrm{El}$ Asnam region, Algeria, at $2^{\circ} \mathrm{E}$, where earthquakes with $\mathrm{M}_{\mathrm{s}}>6$ occurred in $1954\left(\mathrm{M}_{\mathrm{s}}=6.5\right)$ and $1980\left(\mathrm{M}_{\mathrm{s}}=7.3\right)$.

Historical seismicity (shocks with maximum intensity of IX or $\mathrm{X}$, occurring between 1500 and 1910 for the region are represented in Figure 3 (MÉzCUA and Martinez Solares, 1983; MuÑoz and UdíAs, 1988; Mokrane et al., 1994). Larger earthquakes $(\mathrm{Io}=\mathrm{X})$ are located west of S. Vicente Cape (Lisbon earthquake, 1755), southern Iberia (1829 and 1884) and northeastern Algeria $(1716,1790,1825,1858$ and 1891). In northern Morocco only one large earthquake has occurred with maximum intensity IX in 1909. In Spain, except for the earthquake of 1504 (Carmona, Sevilla), shocks are located very near the coast in the south and southeast. Another area of high activity is the Lower Tajo Valley, near Lisbon, Portugal.

A selection of focal mechanisms for shallow earthquakes in this region taken from previous studies, together with four new solutions estimated in this study (Annex 1), are shown in Figure 4 and Table 1. Criteria used for the selection of the 


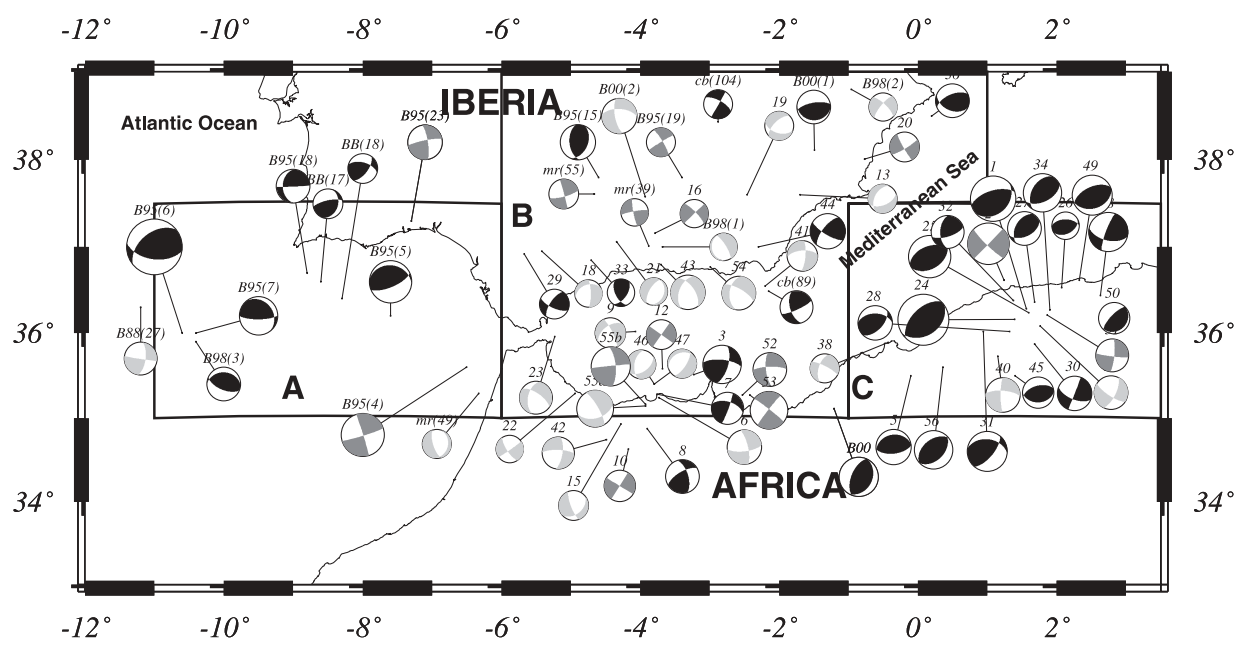

Figure 4

Focal mechanisms for shallow earthquakes $(\mathrm{h}<40 \mathrm{~km})$ and $\mathrm{m}_{\mathrm{b}} \geq 5.0$, before 1975 and $\mathrm{m}_{\mathrm{b}} \geq 4.0$ after 1975. In black thrusting solutions, in dark grey strike-slip and in grey normal solutions. Size is proportional to magnitude. Numbers correspond to Table 1.

solutions are: $m_{b} \geq 5$ for shocks that occurred before 1975 , and $m_{b} \geq 4$ for shocks after 1975. The new solutions are based on more than 15 polarity data, and nodal planes are well defined. Six solutions were obtained from modelling or inversion of body waves and the rest from polarities of $P$ waves. This selection of focal mechanisms has been chosen so that the solutions represent the regional stress pattern, and the local effects present in smaller earthquakes are avoided.

From Figure 4 we observe that fault plane solutions show predominantly thrusting motion in areas $\mathrm{A}$ and $\mathrm{C}$ (Gulf of Cadiz and Algeria regions), with an average horizontal compression in the NNW-SSE direction. There exist some strikeslip mechanisms in A (events B95 (4), B95 (23)) and in B (events 2, 51, 40), which are also compatible with a horizontal compression in the NNW-SSE direction. For these earthquakes tension axes are also horizontal in the NNE-SSW direction. Strike-slip solutions have a predominantly E-W plane with right-lateral motion, the northern block moving east. In area B (central region) focal mechanisms show a greater variety of solutions. Solutions correspond to normal faulting (5), strike-slip mechanisms with a large component of normal motion (10), reverse faulting (4), strike-slip with a large component of reverse motion (7), and pure strike-slip faulting (15). Thus a normal component of motion is present in 15 shocks. In this respect area $\mathrm{B}$ differs from $\mathrm{A}$ and $\mathrm{C}$, where the predominant motion is of reverse character. Most solutions in area B are compatible with a stress pattern consisting of a general horizontal tension axis in the E-W direction and a horizontal pressure axis in the NW-SE direction. Solutions with a large normal component and vertical $P$ axis are more frequent on the south coast of Spain and in the Alboran Sea. 
Table 1

Solutions for focal mechanisms of shallow earthquakes represented in Figure 4. $\phi:$ strike, $\delta:$ dip, $\lambda:$ slip. NF is the reference plotted with each solution

\begin{tabular}{|c|c|c|c|c|c|c|c|c|c|}
\hline Date & Lat. N & Long.E & Depth & $\mathrm{M}$ & $\phi$ & $\delta$ & $\lambda$ & NF & Ref. \\
\hline 190551 & 37.58 & -3.93 & 30 & 5.1 & 169 & 69 & -35 & $\mathrm{~B} 00(2)$ & 9 \\
\hline 090954 & 36.28 & 1.57 & 10 & 6.5 & 253 & 61 & 104 & 1 & 1 \\
\hline 100954 & 36.62 & 1.24 & 30 & 6.0 & 44 & 90 & -8 & 2 & 1 \\
\hline 230859 & 35.51 & -3.23 & 20 & 5.5 & 276 & 70 & 153 & 3 & 1 \\
\hline 051260 & 35.60 & -6.50 & 15 & 6.2 & 73 & 86 & -178 & B95(4) & 2 \\
\hline 150364 & 36.2 & -7.60 & 12 & 6.1 & *276 & 24 & 117 & B95(5) & 2 \\
\hline 130767 & 35.50 & -0.10 & 5 & 5.1 & 260 & 30 & 87 & 5 & 1 \\
\hline 170468 & 35.24 & -3.73 & 22 & 5.0 & 83 & 70 & -162 & 6 & 1 \\
\hline 301068 & 35.28 & -3.76 & 5 & 4.6 & 286 & 55 & 145 & 7 & 1 \\
\hline 280269 & 36.10 & -10.60 & 22 & 8.0 & 231 & 47 & 54 & B95(6) & 2 \\
\hline 050569 & 36.00 & -10.40 & 29 & 5.5 & 324 & 24 & 142 & B95(7) & 2 \\
\hline 070470 & 34.87 & -3.90 & 5 & 4.8 & 244 & 64 & 151 & 8 & 1 \\
\hline 180472 & 36.30 & -11.20 & 15 & 4.7 & 8 & 65 & -2 & B88(27) & 7 \\
\hline 221172 & 36.02 & -4.07 & 5 & 4.4 & 234 & 50 & -15 & 9 & 1 \\
\hline 290473 & 34.63 & -4.17 & 10 & 4.5 & 212 & 90 & 1 & 10 & 1 \\
\hline 140774 & 35.58 & -3.68 & 5 & 4.3 & 305 & 90 & 180 & 12 & 1 \\
\hline 060677 & 37.60 & -1.70 & 10 & 4.2 & 208 & 45 & -121 & 13 & 1 \\
\hline 150777 & 35.17 & -3.73 & 13 & 4.0 & 211 & 70 & -25 & 14 & 1 \\
\hline 240279 & 34.93 & -4.28 & 5 & 4.3 & 51 & 40 & -23 & 15 & 1 \\
\hline 200379 & 37.16 & -3.79 & 5 & 4.1 & 316 & 78 & -179 & 16 & 1 \\
\hline 210479 & 35.03 & -4.00 & 5 & 4.0 & 173 & 71 & 148 & 17 & 1 \\
\hline 010579 & 36.95 & -5.42 & 24 & 4.0 & 249 & 35 & -24 & 18 & 1 \\
\hline 140579 & 37.70 & -2.46 & 5 & 4.2 & 107 & 49 & -40 & 19 & 1 \\
\hline 251079 & 38.01 & -0.77 & 20 & 4.3 & 59 & 81 & -7 & 20 & 1 \\
\hline 221279 & 37.06 & -4.34 & 40 & 4.0 & 210 & 64 & -86 & 21 & 1 \\
\hline 100280 & 35.29 & -4.94 & 5 & 4.0 & 55 & 85 & -18 & 22 & 1 \\
\hline 220680 & 35.96 & -5.93 & 30 & 4.7 & 304 & 66 & -135 & 23 & 1 \\
\hline 101080 & 36.16 & 1.39 & 5 & 7.3 & $* 225$ & 54 & 83 & 24 & 1 \\
\hline 101080 & 36.24 & 1.59 & 10 & 6.1 & 58 & 43 & 81 & 25 & 1 \\
\hline 131080 & 36.53 & 2.07 & 5 & 4.0 & 63 & 42 & 69 & 26 & 1 \\
\hline 301080 & 36.26 & 1.68 & 5 & 4.8 & 210 & 46 & 64 & 27 & 1 \\
\hline 081180 & 36.02 & 1.32 & 5 & 5.0 & 270 & 45 & 126 & 28 & 1 \\
\hline 031280 & 36.92 & -5.67 & 27 & 4.3 & 114 & 68 & 155 & 29 & 1 \\
\hline 051280 & 35.87 & 1.68 & 5 & 5.0 & 112 & 61 & -179 & 30 & 1 \\
\hline 071280 & 36.02 & 0.94 & 5 & 5.8 & 277 & 40 & 140 & 31 & 1 \\
\hline 150181 & 36.38 & 1.38 & 8 & 4.7 & 181 & 53 & 29 & 32 & 1 \\
\hline 210181 & 36.85 & -4.71 & 5 & 4.0 & 153 & 56 & 46 & 33 & 1 \\
\hline 010281 & 36.27 & 1.90 & 11 & 5.5 & 210 & 43 & 64 & 34 & 1 \\
\hline 140281 & 36.08 & 1.76 & 26 & 4.9 & 26 & 67 & -18 & 35 & 1 \\
\hline 050381 & 38.50 & 0.20 & 5 & 4.9 & 113 & 42 & 128 & 36 & 1 \\
\hline 200381 & 35.13 & -3.90 & 5 & 4.0 & 164 & 89 & 133 & 37 & 1 \\
\hline 190481 & 35.89 & -0.43 & 16 & 4.2 & 198 & 57 & -16 & 38 & 1 \\
\hline 070481 & 35.12 & -3.98 & & 4.0 & 182 & 75 & 132 & 39 & 1 \\
\hline 151182 & 35.73 & 1.15 & 7 & 5.0 & 274 & 70 & -169 & 40 & 1 \\
\hline 060183 & 36.49 & -2.15 & 12 & 4.7 & 163 & 58 & 14 & $\operatorname{cb}(89)$ & 3 \\
\hline 200383 & 36.55 & -2.20 & 6 & 4.4 & 266 & 62 & -18 & 41 & 1 \\
\hline 241183 & 34.74 & -4.49 & 40 & 4.6 & 272 & 74 & -23 & 42 & 1 \\
\hline 240684 & 36.80 & -3.70 & 5 & 5.0 & 201 & 48 & -46 & 43 & 1 \\
\hline
\end{tabular}


Table 1 (contd.)

\begin{tabular}{|c|c|c|c|c|c|c|c|c|c|}
\hline Date & Lat. N & Long.E & Depth & $\mathrm{M}$ & $\phi$ & $\delta$ & $\lambda$ & $\mathrm{NF}$ & Ref. \\
\hline 130984 & 37.00 & -2.30 & 9 & 5.1 & 121 & 73 & 156 & 44 & 1 \\
\hline 100485 & 38.43 & -2.88 & 5 & 4.2 & 298 & 67 & -3 & $\mathrm{cb}(104)$ & 3 \\
\hline 030585 & 35.50 & 1.40 & & 4.5 & 225 & 54 & 83 & 45 & 1 \\
\hline 260585 & 37.80 & -4.60 & 5 & 5.1 & 174 & 51 & 70 & B95(15) & 2 \\
\hline 201086 & 36.70 & -8.80 & 37 & 4.8 & 180 & 37 & 3 & B95(18) & 2 \\
\hline 110387 & 37.80 & -3.40 & 7 & 4.2 & 329 & 80 & 2 & B95(19) & 2 \\
\hline 091287 & 35.40 & -3.82 & 14 & 4.2 & 54 & 49 & -58 & 46 & 1 \\
\hline 051088 & 35.40 & -3.80 & 11 & 4.2 & 248 & 26 & -58 & 47 & 1 \\
\hline 311088 & 36.44 & 2.63 & 13 & 5.7 & 103 & 55 & 167 & 48 & 1 \\
\hline 051288 & 37.01 & -3.88 & 5 & 4.0 & 169 & 82 & 73 & $\operatorname{mr}(39)$ & 6 \\
\hline 291089 & 36.61 & 2.33 & 31 & 5.8 & 242 & 55 & 87 & 49 & 1 \\
\hline 201289 & 37.30 & -7.30 & 23 & 5.0 & 351 & 77 & 10 & B95(23) & 2 \\
\hline 090290 & 36.26 & 2.83 & 18 & 4.5 & 49 & 18 & 95 & 50 & 1 \\
\hline 071190 & 37.00 & -3.68 & 2 & 4.0 & 165 & 16 & -74 & B98(1) & 9 \\
\hline 150691 & 35.90 & -10.40 & 6 & 4.8 & 273 & 30 & 73 & B98(3) & 9 \\
\hline 140891 & 38.80 & -0.96 & 4 & 4.1 & 314 & 72 & -164 & B98(2) & 9 \\
\hline 190192 & 36.21 & 1.86 & 4 & 4.7 & 277 & 85 & -169 & 51 & 1 \\
\hline 120392 & 35.27 & -2.53 & 8 & 4.8 & 268 & 76 & -161 & 52 & 1 \\
\hline 160293 & 36.60 & -8.60 & 26 & 4.3 & 17 & 33 & 34 & $\mathrm{BB}(17)$ & 5 \\
\hline 010593 & 35.29 & -6.33 & 30 & 4.2 & 15 & 25 & -60 & $\operatorname{mr}(49)$ & 6 \\
\hline 230593 & 35.27 & -2.42 & 6 & 5.4 & 308 & 86 & 4 & 53 & 1 \\
\hline 220693 & 36.40 & -8.30 & 15 & 4.3 & 37 & 62 & 40 & $\mathrm{BB}(18)$ & 5 \\
\hline 231293 & 36.77 & -2.99 & 8 & 4.9 & 300 & 70 & -130 & 54 & 1 \\
\hline 260594 & 35.14 & -3.92 & 7 & 5.3 & $* 330$ & 77 & -45 & $55 \mathrm{a}$ & 1 \\
\hline 260594 & 35.16 & -3.92 & 8 & 5.7 & *355 & 79 & 2 & $55 \mathrm{~b}$ & 1 \\
\hline 180894 & 35.60 & 0.36 & 4 & 5.7 & $* 58$ & 45 & 95 & 56 & 1 \\
\hline 160496 & 37.61 & -4.66 & 8 & 4.3 & 75 & 76 & -179 & $\operatorname{mr}(55)$ & 6 \\
\hline 020299 & 38.11 & -1.49 & 5 & 4.8 & 260 & 67 & 89 & B00(1) & 4 \\
\hline 221299 & 35.26 & -1.45 & 6 & 5.6 & $* 25$ & 31 & 92 & B00 & 8 \\
\hline
\end{tabular}

1. BeZzeghoud and Buforn. (1999); 2. Buforn et al. (1995); 3. COCA and Buforn (1994); 4. Buforn and Sanz de Galdeano (2001); 5. Borges et al. (2001); 6. Mezcua and Rueda (1997); 7. Buforn et al. (1988a); 8. Yelles-Chaouche et al., This issue; 9. This paper; *Modeling or inversion of body waves.

\section{Intermediate Depth Earthquakes}

Important seismic activity at intermediate depth $(150>\mathrm{h}>40 \mathrm{~km})$ is present in parts A and B, as can be seen in Figure 2 (MunuerA, 1963; HATZFELD, 1978; Grimison and Cheng, 1986; Buforn et al., 1988b, 1991a, b, 1997; SEBer et al., 1996; Serrano et al., 1998). This activity is shown in more detail for the period 1980-1999 and $m_{b} \geq 3.5$, in Figure 5 (I.G.N. Data File). The reliability of depth determinations for this time period was improved by the installation of the network of the IGN in Spain (Tejedor and García, 1993). Magnitudes $\mathrm{m}_{\mathrm{b}}$ of earthquakes in this figure are between 3.5 and 5. In part A, intermediate-depth shocks are spread over a band approximately 100-km wide, (between $36^{\circ} \mathrm{N}$ and $37^{\circ} \mathrm{N}$ ), extending E-W from $8^{\circ} \mathrm{W}$ to $11^{\circ} \mathrm{W}$. The most important concentration of foci at intermediate depth 


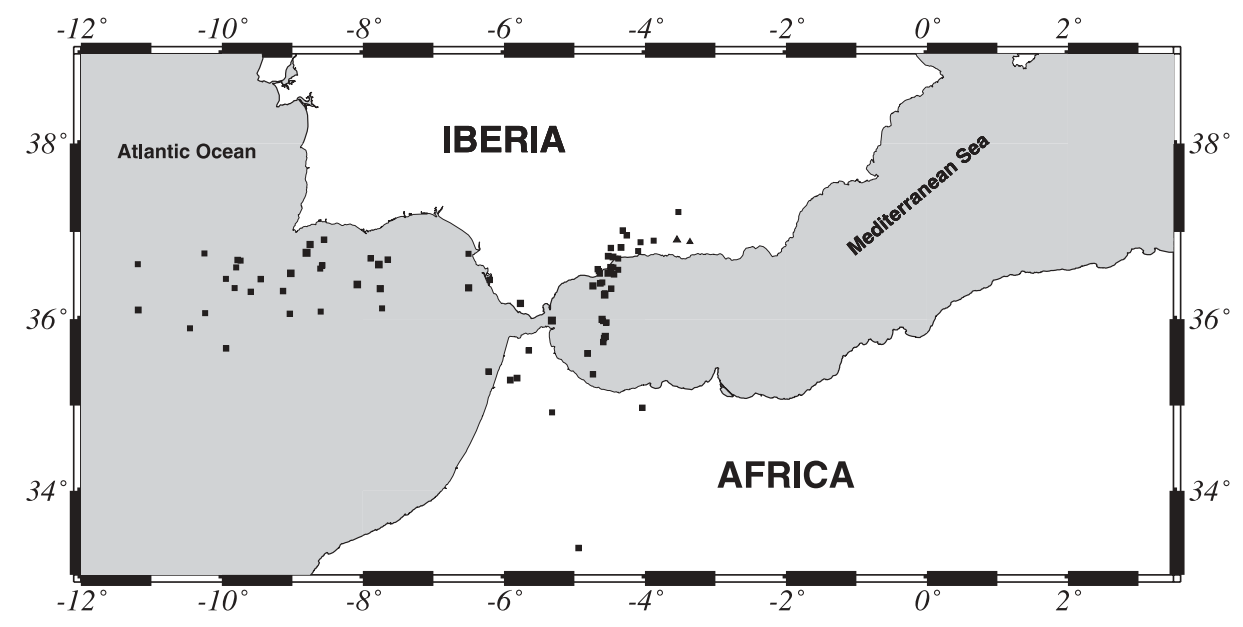

Figure 5

Distribution of epicenters at intermediate depth $(40<\mathrm{h}<150 \mathrm{~km}$, squares) and very deep earthquakes (h $>600 \mathrm{~km}$, triangles). The period represented is 1980-1999 (Instituto Geográfico Nacional, Data File).

is in part B, at the eastern side of the Strait of Gibraltar in a narrow N-S trending band less than $50-\mathrm{km}$ wide, centered at $4.5^{\circ} \mathrm{W}$ and extending from $35^{\circ} \mathrm{N}$ to $37^{\circ} \mathrm{N}$. Thus the distribution of intermediate-depth shocks differs in area $\mathrm{A}$ (E-W trend) from that of area B (N-S trend). No intermediate depth seismic activity is observed east of $3^{\circ} \mathrm{W}$ in Spain, Morocco or Algeria.

A vertical E-W cross section of the seismicity, showing the distribution of hypocenters along a band between $12^{\circ} \mathrm{W}$ and $2^{\circ} \mathrm{W}$ and centered at $36^{\circ} \mathrm{N}$, is shown in Figure 6a. From this figure we observe that most earthquakes in part $\mathrm{A}$ have depths less than about $60 \mathrm{~km}$. In part $\mathrm{B}$, at about $4.5^{\circ} \mathrm{W}$ there is a concentration of shocks to depths of $100 \mathrm{~km}$ in a very narrow band of less than $50 \mathrm{~km}$. To the east of this area depths decrease rapidly with maximum depths less than $40 \mathrm{~km}$ to the east of $3^{\circ} \mathrm{W}$ (to Algeria). No intermediate-depth activity is found in part C.

Figures $6 \mathrm{~b}$ and $6 \mathrm{c}$ show N-S vertical cross sections along bands centered at longitudes $9^{\circ} \mathrm{W}$ (Gulf of Cadiz) and $4.5^{\circ} \mathrm{W}$ (western part of the Alboran Sea). For the Gulf of Cadiz (Fig. 6b), most earthquakes occur at depths less than $60 \mathrm{~km}$, with most foci concentrated between latitudes $36^{\circ} \mathrm{N}$ and $37^{\circ} \mathrm{N}$. In the Alboran Sea (Fig. 6c) depths increase to values around $100 \mathrm{~km}$, with an important concentration of hypocenters between 60 and $100 \mathrm{~km}$ occurring between latitudes $35^{\circ} \mathrm{N}$ and $37^{\circ} \mathrm{N}$. These shocks correspond to the narrow band in Figure 6a. There is an apparent gap between 30 and $50 \mathrm{~km}$ for the same latitudes however this may be due to the crustal model used in the hypocentral determinations.

Focal mechanisms for 27 selected intermediate-depth events $\left(m_{b} \geq 3.5\right)$, from previous studies, together with eight solutions determined for this study (Annex 1), are shown in Figure 7 and listed in Table 2. Most solutions correspond to 


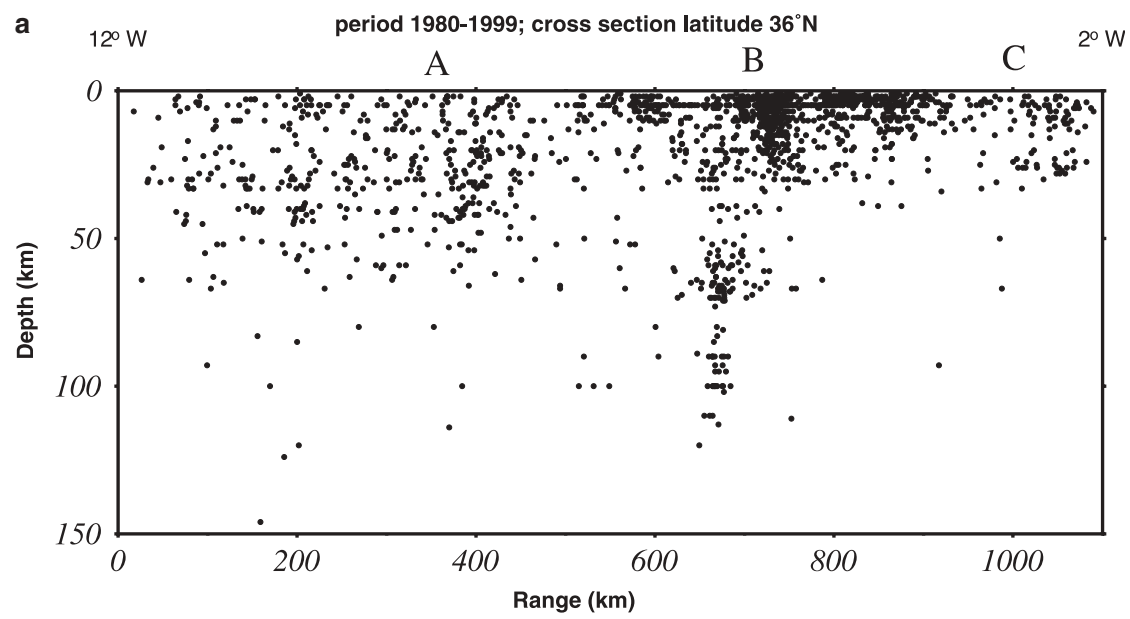

b period 1980-1999; cross section at longitude $9.0^{\circ} \mathrm{W}$
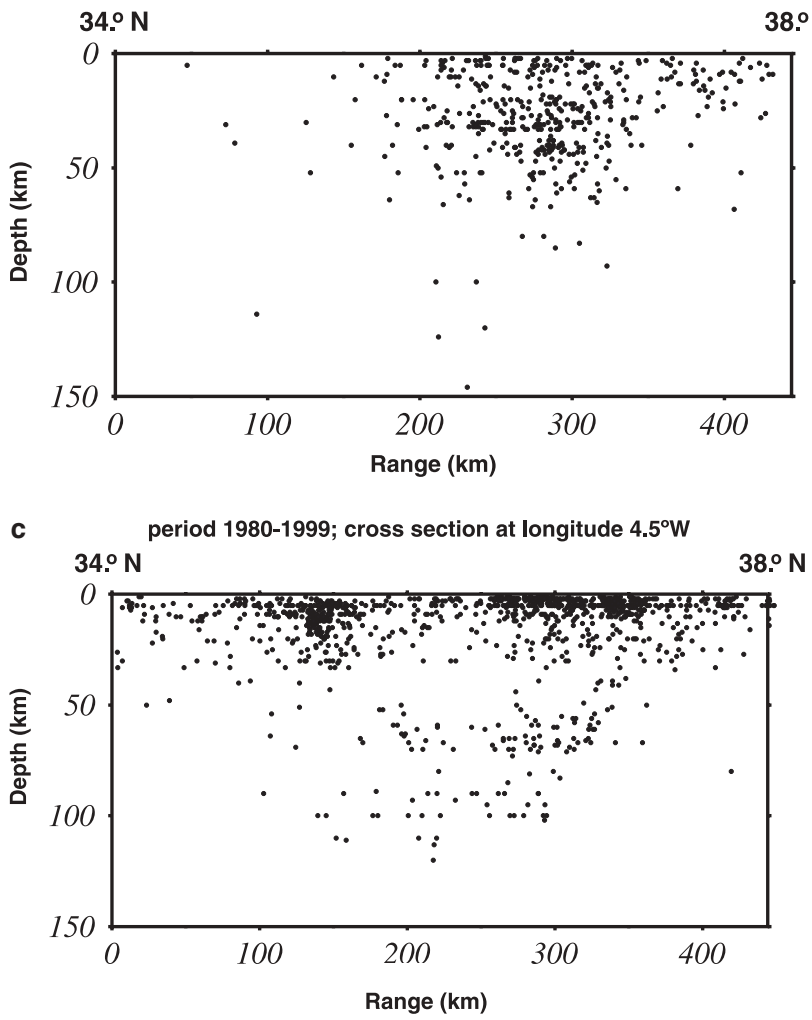

Figure 6

Vertical cross sections for the period 1980-1999 and magnitude greater than or equal to 3.5, (a) E-W section centered along $36^{\circ} \mathrm{N}$, (b) $\mathrm{N}-\mathrm{S}$ centered along $9^{\circ} \mathrm{W}$ and (c) $\mathrm{NS}$ centered along $4.5^{\circ} \mathrm{W}$. 


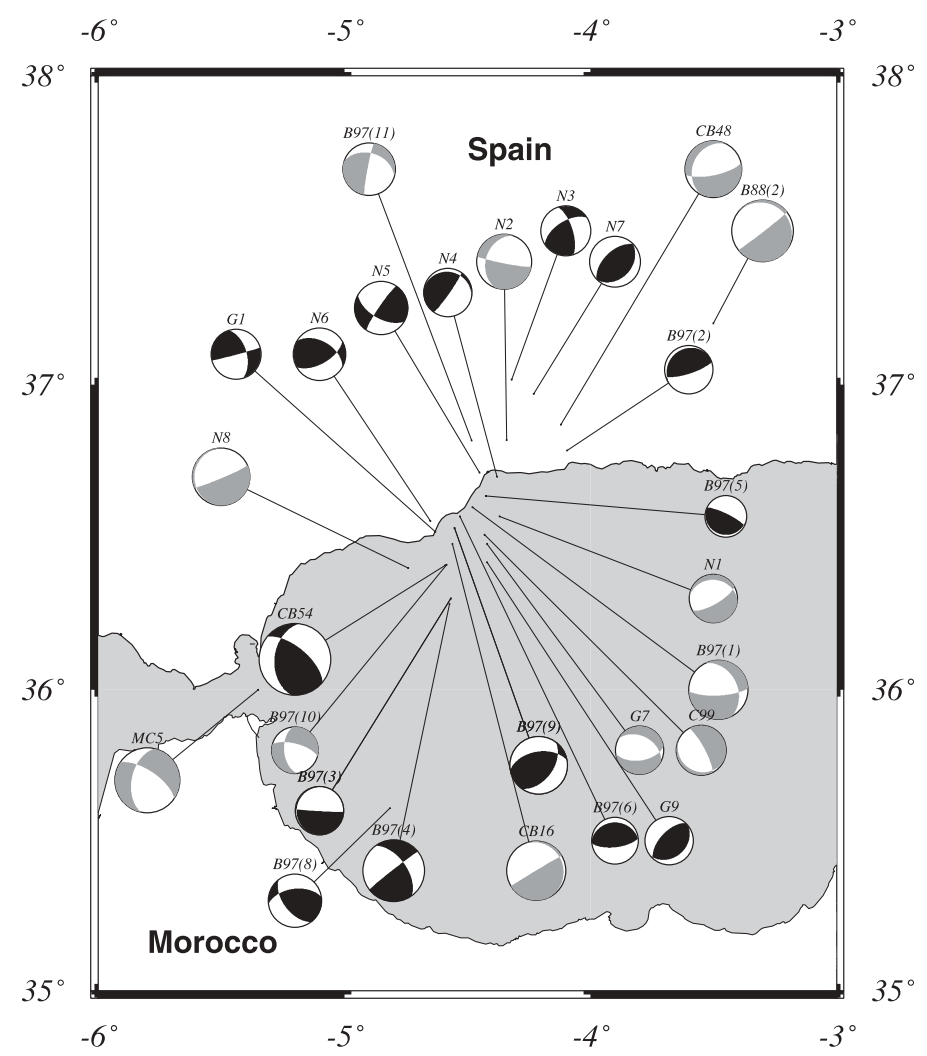

Figure 7

Focal mechanisms for intermediate depth earthquakes $(40<\mathrm{h}<150 \mathrm{~km})$. Thrusting solutions in black and normal solutions in grey. Numbers correspond to Table 2.

earthquakes located very near the Spanish coast, where the concentration of epicenters is greater. Twelve of these solutions were obtained by modelling and inversion of body waves (Table 2) and the rest from first motion of $P$ waves. Most solutions correspond to dip-slip motion, 7 to normal component and 9 to reverse component of motion. In most solutions the nearly vertical nodal plane has a mean orientation NE-SW. Only four shocks have an appreciable strike-slip component of motion. A nearly vertical tension axis has been obtained for 15 earthquakes ( 7 of them estimated from modelling or inversion of body waves).

\section{Deep Earthquakes}

An important feature of the seismicity of this region is the occurrence of very deep earthquakes at a depth of about $630 \mathrm{~km}$. The largest of these earthquakes $(M=7)$ took place in 1954. These are the deepest earthquakes in the Mediterranean 
Table 2

Solutions for focal mechanisms of intermediate depth earthquakes represented in Figure 7. $\phi:$ strike, $: \delta$ dip, $\lambda$ : slip. NF is the reference plotted with each solution

\begin{tabular}{|c|c|c|c|c|c|c|c|c|c|}
\hline Date & Lat. N. & Long.E & Depth & $\mathrm{M}$ & $\phi$ & $\delta$ & $\lambda$ & $\mathrm{NF}$ & Ref. \\
\hline 130268 & 36.48 & -4.56 & 91 & 4.3 & 334 & 10 & 5 & CD16 & 3 \\
\hline 130674 & 36.87 & -4.12 & 60 & 4.1 & 78 & 72 & -69 & CB48 & 3 \\
\hline 070875 & 36.41 & -4.59 & 105 & 5.2 & 186 & 42 & 138 & CB54 & 3 \\
\hline 200679 & 37.20 & -3.50 & 60 & 4.5 & 52 & 87 & -102 & B88(2) & 4 \\
\hline 220680 & 35.96 & -5.23 & 81 & 4.7 & 304 & 76 & -135 & MC5 & 5 \\
\hline 130586 & 36.60 & -4.48 & 90 & 4.3 & $* 87$ & 74 & -123 & B97(1) & 1 \\
\hline 270387 & 36.79 & -4.10 & 79 & 3.5 & $* 69$ & 72 & 76 & B97(2) & 1 \\
\hline 300588 & 36.52 & -4.63 & 80 & 3.6 & 75 & 88 & 35 & G1 & 6 \\
\hline 281188 & 36.30 & -4.57 & 100 & 3.5 & $* 93$ & 88 & -85 & B97(3) & 1 \\
\hline 121288 & 36.28 & -4.57 & 95 & 4.5 & $* 232$ & 87 & 146 & B97(4) & 1 \\
\hline 190789 & 36.64 & -4.43 & 95 & 3.0 & $* 296$ & 79 & 94 & B97(5) & 1 \\
\hline 060290 & 36.57 & -4.53 & 68 & 3.4 & $* 270$ & 23 & 96 & B97(6) & 1 \\
\hline 130490 & 35.61 & -4.82 & 89 & 3.9 & $* 263$ & 53 & 45 & B97(8) & 1 \\
\hline 020590 & 36.53 & -4.55 & 95 & 4.2 & $* 36$ & 49 & 57 & B97(9) & 1 \\
\hline 181190 & 36.41 & -4.59 & 85 & 3.4 & $* 175$ & 51 & -30 & B97(10) & 1 \\
\hline 250891 & 36.82 & -4.48 & 58 & 3.8 & $* 286$ & 39 & -173 & B97(11) & 1 \\
\hline 140392 & 36.51 & -4.43 & 64 & 3.6 & $* 118$ & 14 & -123 & C99 & 2 \\
\hline 030992 & 36.48 & -4.42 & 86 & 3.5 & 298 & 41 & -61 & G7 & 6 \\
\hline 091193 & 36.42 & -4.42 & 70 & 3.5 & 223 & 60 & 86 & G9 & 6 \\
\hline 010194 & 36.57 & -4.37 & 68 & 3.5 & 60 & 71 & -103 & N1 & 7 \\
\hline 170395 & 36.82 & -4.34 & 56 & 4.0 & 100 & 85 & -56 & N2 & 7 \\
\hline 181195 & 37.02 & -4.32 & 52 & 3.6 & 238 & 59 & 154 & N3 & 7 \\
\hline 281195 & 36.70 & -4.38 & 68 & 3.5 & 35 & 84 & 76 & N4 & 7 \\
\hline 220696 & 36.71 & -4.45 & 68 & 3.9 & 120 & 58 & 172 & N5 & 7 \\
\hline 271296 & 36.56 & -4.65 & 59 & 3.8 & 60 & 60 & 49 & N6 & 7 \\
\hline 180397 & 36.96 & -4.23 & 56 & 3.7 & 43 & 34 & 87 & N7 & 7 \\
\hline 200897 & 36.40 & -4.65 & 68 & 4.2 & 67 & 86 & -63 & N8 & 7 \\
\hline
\end{tabular}

1. Buforn et al. (1997); 2. CoCA (1999); 3. CoCA and Buforn (1994); 4. Buforn et al. (1988b); 5. Medina and Cherkaoui (1992); 6. Morales et al. (1999); 7. This paper; *wave-form modelling or inverison.

region and their origin is still an undecided question. During the period represented in Figure 2 very deep events occurred in 1990 and 1993 (Table 3). The 1990 event $\left(\mathrm{M}_{\mathrm{w}}=4.8\right)$ has been studied previously (BUFORN et al., 1991b, 1997) and the 1993 earthquake, with a lower magnitude $\left(\mathrm{M}_{\mathrm{w}}=4.4\right)$, is studied in this paper (Annex 1). Their foci are located to the east of the concentration of the intermediate depth earthquakes at about the same location as that of the 1954 and 1973 events (CHUNG and KANAMORI, 1976; Buforn et al., 1991a, 1997). This occurrence of deep seismicity is concentrated in a very small area inland south of Granada, the east of the intermediate-depth seismicity that has most foci in the Alboran Sea. Focal mechanism solutions for deep earthquakes are all very similar (Fig. 8 and Table 3). Solutions have a vertical plane oriented N-S and the other nearly horizontal. Pressure and tension axes dip about $45^{\circ}$, with the pressure axis dipping to the east and the tension axis to the west. In this regard solutions differ from those for the 
Table 3

Solution for focal mechanisms of deep depth earthquakes represented in Figure 8. $\phi:$ strike, $\delta:$ dip, $\lambda:$ slip. NF is the reference plotted with each solutions

\begin{tabular}{cccccccccc}
\hline Date & Lat. N. & Long.E & Depth & M & $\phi$ & $\delta$ & $\lambda$ & NF & Ref. \\
\hline 210354 & 37.00 & -3.70 & 640 & 7.0 & 179 & 88 & -122 & B91(1) & 1 \\
300173 & 36.90 & -3.70 & 660 & 4.8 & 191 & 74 & -56 & B91(2) & 1 \\
080390 & 37.00 & -3.60 & 637 & 4.8 & 177 & 62 & -91 & B91(8) & 1 \\
310793 & 36.80 & -3.43 & 663 & 4.4 & 177 & 60 & -91 & B02 & 2 \\
\hline
\end{tabular}

1. Buforn et al. 1991a; 2. This paper

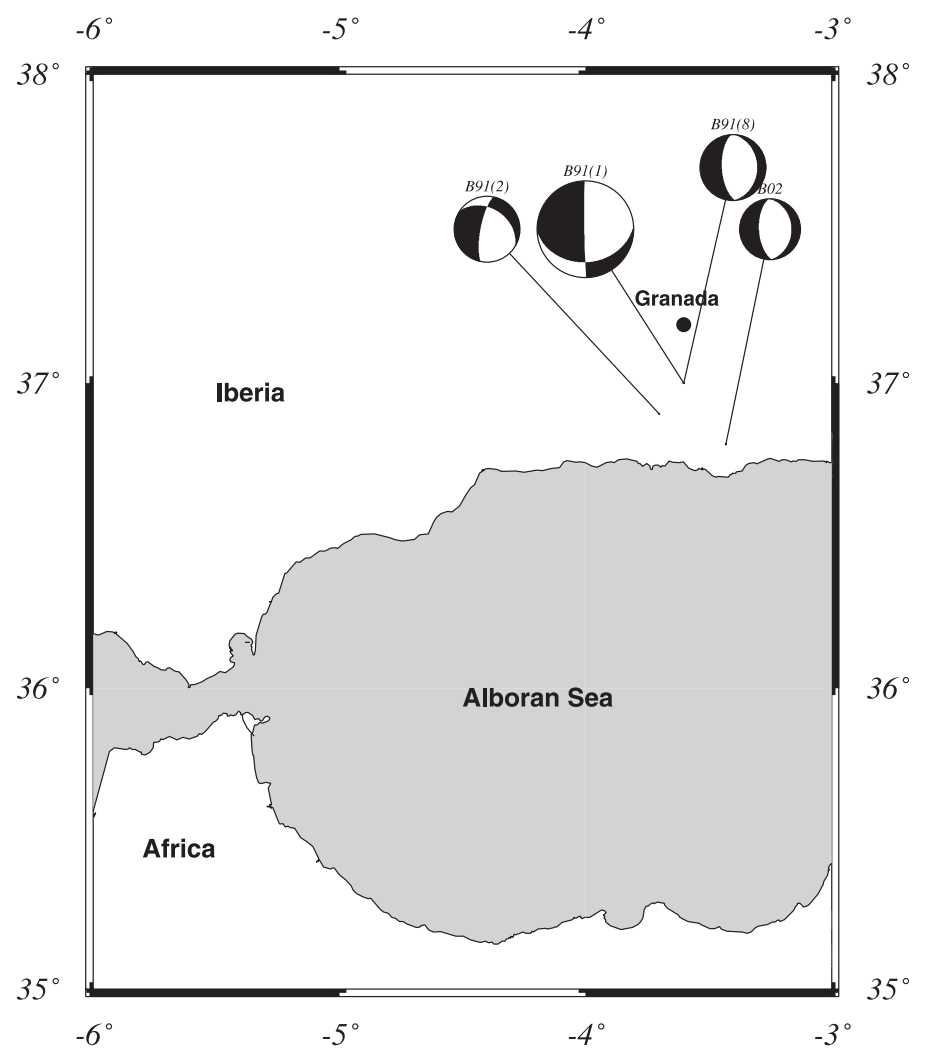

Figure 8

Focal mechanisms for very deep depth earthquakes $(\mathrm{h}>600 \mathrm{~km})$. Numbers correspond to Table 3

intermediate-depth earthquakes in which pressure axes dip to the south or southeast. From Figures 7 and 8 we observe, as a common characteristic of the focal mechanisms for intermediate-depth and very deep earthquakes, a nearly vertical plane. However the orientation of this plane is approximately E-W for intermediate shocks and N-S for the very deep ones. 


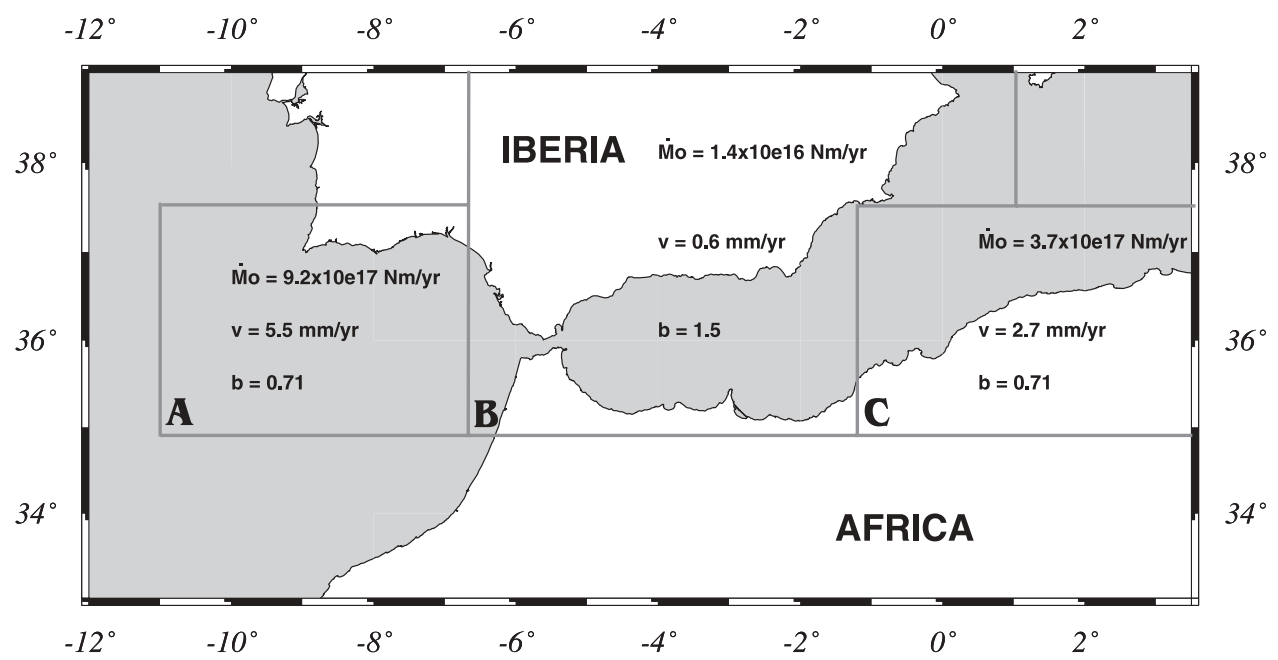

Figure 9

Moment rate, slip velocity and b values for the three studied areas (A, B and C).

\section{Moment Rates, Slip Velocities and b Values}

From the seismicity and focal mechanisms of shallow and intermediate-depth events, different behavior of the plate boundary in the three areas $\mathrm{A}, \mathrm{B}$ and $\mathrm{C}$ from the Gulf of Cadiz to Algeria may be deduced. In order to quantify the characteristics of the seismicity in these three areas, the seismic moment rate, slip velocity and $b$ value have been estimated for each of them. Results are shown in Figure 9. The moment rate was estimated from shallow earthquakes occurring in each area during the period 1900-1999 with magnitude $\mathrm{m}_{\mathrm{b}} \geq 5$. We used an empirical relation between magnitude $\mathrm{m}_{\mathrm{b}}$ and scalar seismic moment $\mathrm{M}_{\mathrm{o}}$ obtained from events with $\mathrm{M}_{\mathrm{o}}$ values determined from spectra of body waves. The relation is similar to that obtained by other authors (BUfORN et al., 1988a; EKSTRÖM and DZIEWOnSKI, 1988; BADAl et al., 2000).

$$
\log \mathbf{M}_{0}=1.54 \mathbf{m}_{b}+8.7 .
$$

The moment rate $\mathrm{M}_{0}$ was estimated by dividing the sum of the scalar seismic moment in each of the three areas by the time period (100 years).

Average slip velocity was estimated from the moment rate according to the expression

$$
\Delta \dot{u}=\dot{M}_{0} / \mu S,
$$

where $\mu$ is the rigidity coefficient and $\mathrm{S}$ the fault area. As an estimate of the slip velocity we used $\mu=3 \times 10^{4} \mathrm{MPa}$, and for $S$ we took the area of a vertical fault with a length of $550 \mathrm{~km}$ for parts A and B and $440 \mathrm{~km}$ for part C, and a width of $10 \mathrm{~km}$ 
(the average depth for shallow shocks). This is equivalent to considering a fault with these dimensions as the origin of the shallow seismicity (Fig. 2).

The $b$ values were obtained using earthquakes with magnitude $\mathrm{m}_{\mathrm{b}} \geq 3.0$ for the period 1950-1999. For this period the catalogue is considered complete for these magnitudes.

For areas $\mathrm{A}$ and $\mathrm{C}$ the same order of magnitude for the moment rate was obtained: $9.2 \times 10^{17} \mathrm{Nm} / \mathrm{yr}$ for $A$ and $3.7 \times 10^{17} \mathrm{Nm} / \mathrm{yr}$ for $\mathrm{C}$. These values are conditioned by the large earthquakes that occurred in area A in 1964 and 1969 and in area $C$ in 1954 and 1980 . However, for area $B$ the moment rate $\left(1.4 \times 10^{16} \mathrm{Nm} / \mathrm{yr}\right)$ is nearly two orders of magnitude lower than that obtained for $\mathrm{A}$ and one order of magnitude lower than that for $\mathrm{C}$. This is due to the fact that the maximum magnitude of earthquakes during the 20th century in area B is lower than 6 (largest shallow earthquake was $M_{\mathrm{s}}=5.1$ in 1951).

Values of slip velocity show similar results as those of moment rate: $5.5 \mathrm{~mm} / \mathrm{yr}$ and $2.7 \mathrm{~mm} / \mathrm{yr}$ for areas $\mathrm{A}$ and $\mathrm{C}$ and $0.6 \mathrm{~mm} / \mathrm{yr}$ for area B. We have compared these results with the relative motions of Africa with relation to Eurasia predicted by the models NUVEL-1a (DEMETs et al., 1990) and DEOSK2 (Rui Fernandes, personal communication) (Table 4). These values have been estimated at the following points: $36.25^{\circ} \mathrm{N},-8.5^{\circ} \mathrm{W}$ for area $\mathrm{A} ; 37.0^{\circ} \mathrm{N},-2.5^{\circ} \mathrm{W}$ for area $\mathrm{B}$ and $36.25^{\circ} \mathrm{N}, 1.25^{\circ} \mathrm{E}$ for area C. For area A, similar values are obtained in our study and by NUVEL-1a and DEOSK2 (Table 4), about $5 \mathrm{~mm} / \mathrm{yr}$ in each case. For area $\mathrm{C}$ our velocity of $2.7 \mathrm{~mm} / \mathrm{yr}$ is approximately $50 \%$ of the value obtained using NUVEL-1a and DEOSK2 models. However, the largest difference occurs in area $\mathrm{B}$, where the velocity predicted by the models is very similar $(5.2 \mathrm{~mm} / \mathrm{yr}$ and $5.4 \mathrm{~mm} / \mathrm{yr}$, respectively) while our estimations give only $0.6 \mathrm{~mm} / \mathrm{yr}$, that is only about $10 \%$ of the modeled values. This may indicate that only a small fraction of the deformation was released seismically during the $20^{\text {th }}$ century.

The $b$ value for each area is as follows: in area $\mathrm{B}$ it is 1.5 , and in both areas $\mathrm{A}$ and $\mathrm{C}$ it is 0.71 . The difference in $b$ values in areas $\mathrm{A}$ and $\mathrm{C}$ and area $\mathrm{B}$ corresponds to the different behavior of the seismic activity, with a large number of small to moderate earthquakes and an absence of large shocks in the last 50 years in area B, and larger earthquakes and a lower number of small ones in areas $\mathrm{A}$ and $\mathrm{C}$.

Table 4

Values of slip velocity obtained from NUVEL 1a, DEOSK2 models and in this study

\begin{tabular}{cccc}
\hline & NUVEL 1aa $(\mathrm{mm} / \mathrm{yr})$ & DEOSK2 $(\mathrm{mm} / \mathrm{yr})$ & This study \\
\hline Gulf of Cadiz & 4.3 & 5.0 & 5.5 \\
Central region & 5.2 & 5.3 & 0.6 \\
Algeria & 5.6 & 5.4 & 2.7 \\
\hline
\end{tabular}


For intermediate-depth and deep earthquakes the moment rate, slip velocity and $b$ values have not been estimated due to the low number of these earthquakes, for which depth determinations are reliable corresponding to recent years only.

In consequence, from Figure 9 we can conclude that in the Gulf of Cadiz and Algeria (areas A and C) the plate boundary between Eurasia and Africa corresponds to an area where the material is relatively rigid and the stresses are released by larger earthquakes. In the Betics, Alboran and Rif regions (area B) the material is more fragmented, with a large number of small faults, and consequently the stresses are released by frequent small to moderate earthquakes. As a consequence, the plate boundary is not well defined in area B and it corresponds to a wide area where deformation is manifested by the continuous occurrence of small earthquakes, and only occasionally, some moderate events occur. However, in the past, large events also have occurred in this area as shown by the historical seismicity (Fig. 3) and the lack of large earthquakes in the 1900-1999 period and the consequent low values of seismic moment rate and slip velocity may be due only to an anomalous period of seismic quiescence during the last century. In the 19th century at least two earthquakes (1829 and 1884) took place in southern Spain with magnitude greater than 6. For this region the time period selected (1900-1999) does not adequately represent the long range seismic activity of the region.

\section{Frohlich Diagrams and Total Moment Tensor}

From the results of focal mechanisms for shallow earthquakes shown in Figure 4 and Table 1, the Frohlich diagrams (Frohlich and ApPERson, 1992) and the total seismic moment tensor for the three areas have been estimated (Fig. 10). The Frohlich diagrams for areas $\mathrm{A}$ and $\mathrm{C}$ show that most solutions correspond to reverse faulting, with only three mechanisms of pure strike-slip in area A and five in area C. A single solution corresponding to a normal motion is found in area $\mathrm{A}$ and there is a total absence of this type of faulting in area C. In area B the stress regime is more complex, strike-slip is the predominant motion and with a large component of normal and reverse faulting. A normal component is most frequent; it is present in 18 cases while reverse component is only present in 10 cases. Five mechanisms show pure normal faulting and four pure reverse faulting.

A problem in the use of the Frohlich diagrams is that in this representation all the earthquakes have the same weight, independent of their magnitude, and in consequence it is difficult to quantify the stress regime in an area. This may be solved with the use of the total seismic moment tensor defined as the sum of the moment tensors calculated from individual solutions:

$$
M_{i j}^{\text {total }}=\sum_{k=1}^{N} M_{0}^{k} m_{i j}^{k},
$$



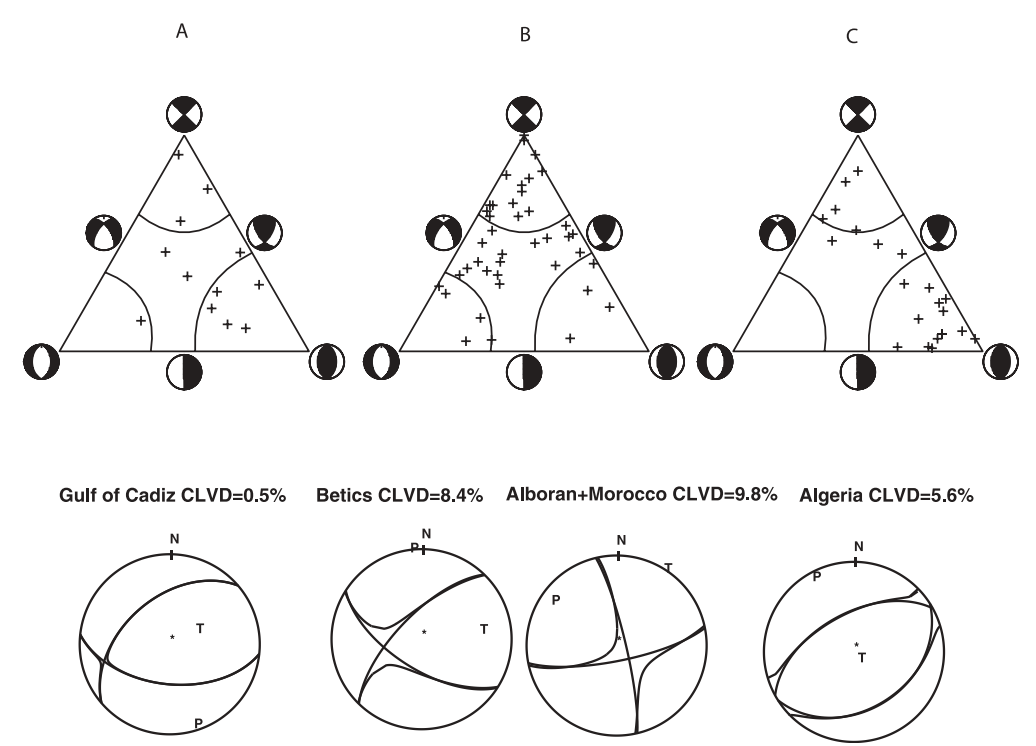

Figure 10

Frohlich diagrams and total seismic moment tensor for shallow earthquakes in the three studied regions. The CLVD component for each region is indicated.

where $k$ is the number of earthquakes, $\mathrm{M}_{0}$ the scalar seismic moment of each event and $\mathrm{m}_{\mathrm{ij}}$ the seismic moment tensor components. Larger earthquakes (with high values of $\mathrm{M}_{0}$ ) make a larger contribution in the estimation of the total seismic moment tensor. Equation (3) was used to estimate the components of total $\mathrm{M}_{\mathrm{ij}}$ for the three regions using the solutions of Table 1. The total seismic moment tensor was separated into a DC and a non-DC (CLVD) component (DZIEWONSKI and Woodhouse, 1983). Results are shown in Figure 10. For area A (Fig. 10) the seismic moment tensor obtained corresponds to thrusting motion. This result is due to the solution of the 1969 earthquake. A similar result has been obtained for area C; the total seismic moment tensor shows thrusting motion due to the solutions of the earthquakes in the El Asnam region, especially that of the 1980 earthquake. The small non-DC components obtained $(0.5 \%$ and $5.6 \%$, respectively) confirm that solutions obtained for both regions are very similar and that large earthquakes control the stress regime in areas $\mathrm{A}$ and $\mathrm{C}$.

In order to obtain coherent results, for area B it was necessary to subdivide the region into two: one part corresponds to the Betics and the other to the Alboran Sea and Morocco. For the Betics the stress regime corresponds to strike-slip faulting with a component of reverse motion, with the pressure axis nearly horizontal and oriented in N-S direction. For Alboran and Morocco the total moment tensor shows strikeslip motion with a small component of normal motion and horizontal tension axis oriented in a NE-SW direction. The amount of non-DC component is $8.4 \%$ and 
9.8\% for the Betics and Alboran and Morocco, respectively. The non-DC values obtained for both parts of area B, each less than $15 \%$, indicates that for these regions the total seismic moment tensor obtained can be considered to represent the stress regime in the area. Thus in the three areas (A, B and C) there is a common orientation of the pressure axis which is horizontal and trending N-S to NW-SE. The tension axis is nearly vertical in areas A and C, and nearly horizontal in B trending E-W to NE-SW.

A similar study has been carried out for the intermediate-depth events (Fig. 11). Frohlich's diagram shows that most of the mechanisms correspond to dip-slip solutions, with a greater component of reverse motions. Only three solutions correspond to pure normal motion while 10 correspond to reverse motion. About 12 solutions correspond to motion on a nearly vertical or horizontal plane. From the total seismic moment tensor, a solution is obtained with a steeply dipping plane oriented NW-SE and a near horizontal plane. The pressure axis is horizontal and trending to the NE and the tension axis is almost vertical, with a small dip to the SE. The amount of non-DC component $(0.8 \%)$ indicates that the stress regime resulting from the focal mechanism solutions for the intermediate-depth events is fairly uniform and may be represented by the solution shown in Figure 11.

For very deep earthquakes Frohlichs diagrams and the total seismic moment tensor have not been estimated. The reason is the small number (only four earthquakes) of similar solutions of focal mechanism and the large magnitude of the

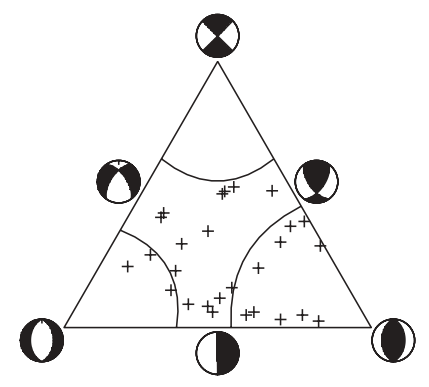

Alboran intermediate depth CLVD $=0.8 \%$

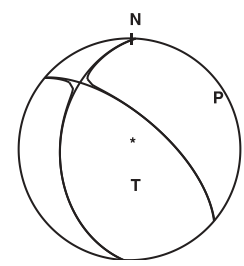

Figure 11

Frohlich diagrams and total seismic moment tensor for intermediate depth earthquakes in the Alboran region, the CLVD component is indicated. 
1954 earthquake. In this case the total seismic moment tensor is controlled by the largest event, with $\mathrm{M}=7$, versus values of less than 5 for the other three earthquakes.

\section{Seismotectonic Interpretation}

Figure 12 depicts a proposed seismotectonic scheme for the studied region. The area delimited by the epicenters of shallow earthquakes (enclosed by the dashed lines) represents the surface expression of the plate boundary. In areas A and C (Gulf of Cadiz and Algeria regions) the plate boundary corresponds to a narrow band well defined by the seismicity, where large earthquakes $(M>7)$ occur in association with horizontal compression N-S to NNW-SSE due to the convergence of Eurasia and Africa. The intermediate-depth earthquakes, with a distribution in the E-W direction and delimited by a narrow band less than $20-\mathrm{km}$ wide that broadens as we move to the Strait of Gibraltar, may also be associated with the convergence process of the

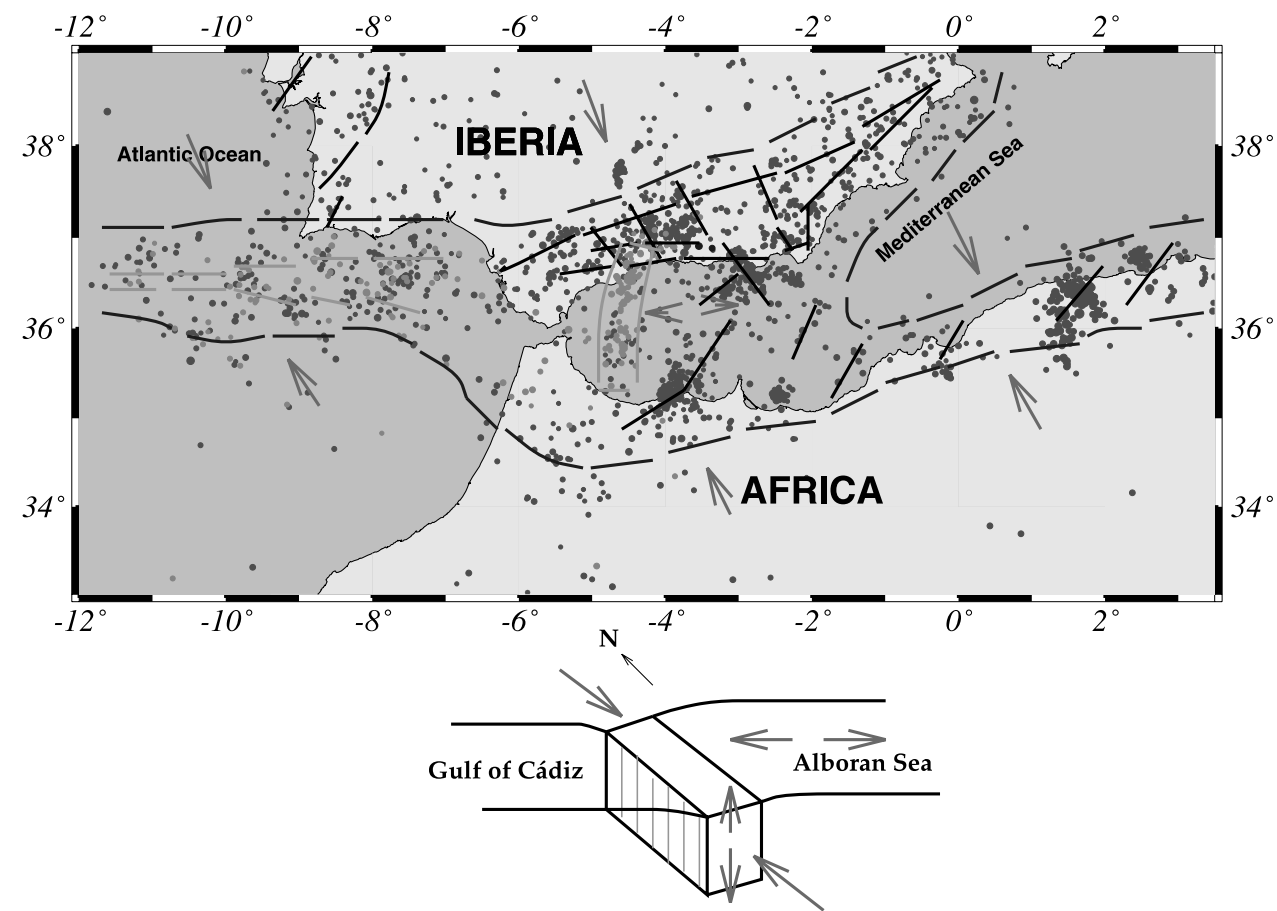

Figure 12

Seismotectonic scheme for the Iberia-Africa region. Shallow earthquakes are plotted in dark, intermediate depth events in grey. Arrows indicate the surface stress regime obtained from focal mechanisms of earthquakes. At bottom the seismogenic block proposed as origin of the intermediate depth seismicity at the western part of Alboran Sea. 
Eurasia-Africa plates. No intermediate-depth earthquakes have been observed in the eastern part of the region (area $\mathrm{C}$ ).

In area B the plate boundary is more diffuse and corresponds to a wider area that includes the Betics, the Alboran Sea and the Rif. It is difficult in this case to identify a simple line that corresponds to the plate boundary. In area B results of moment rate, slip velocity and $b$ values indicate that the strain accumulated in the region is released partly in a continuous seismic activity of moderate magnitude over the whole area. Earthquakes with magnitudes larger than 6 occur at prolonged intervals. From historical seismicity it may be concluded that the 20th century was a period of anomalously low levels of seismic activity in this area. The stress regime obtained from the focal mechanisms of shallow events (Frohlich diagrams and total moment tensor) is compatible with horizontal N-S to NW-SE convergence of Eurasia and Africa. However in the Betics-Alboran area there is also a horizontal extension in an approximately E-W direction.

The existence of important seismic activity at intermediate depth (60 to $150 \mathrm{~km}$ ) extending in a very narrow vertical band $50-\mathrm{km}$ wide in N-S direction may be explained by the existence of a seismogenic block, of approximate dimensions $200-\mathrm{km}$ long, $150-\mathrm{km}$ deep and $50-\mathrm{km}$ wide, on the eastern side of the Strait of Gibraltar. Inside this block the stress regime, deduced from focal mechanisms of earthquakes, corresponds to nearly vertical tension dipping to the SE. Different tectonic models have been proposed for this region, such as some kind of subduction process (BUFORN et al., 1988b, 1991a; MoRALES et al., 1999), extensional collapse of thickened continental lithosphere (Platt and Vissers, 1989; Houseman, 1996), continental lithospheric delamination (DocherTY and BANDA, 1995; MÉzCuA and RUeDA, 1996; SEBER et al., 1996; CALVERT et al., 2000), backarc extension caused by subduction rollback (Morley, 1993; Lonergan and White, 1997; Michard et al., 2002), convective thinning (HousEMAN, 1996) or subduction and breaking of a slab of material (ZECK, 1996). Some of these models, such as continental lithospheric delamination, are not compatible with the presence of the intermediate-depth earthquakes and their focal mechanisms. The results presented here are consistent with the model presented by BUFORN et al. (1997) of an almost vertical slab of material with strike N-S driven by the extensional E-W forces present on the Alboran Sea, and under NW-SE compressive forces. The slab is being stretched downward, possibly by gravitational instability processes. Models which propose very low angle subduction or delamination (CALVERT et al., 2000) are not compatible with the results presented in this paper, due to the vertical distribution of hypocenters. Whatever explanation is given for the tectonics of this region, it must satisfy the geometry of the location of hypocenters and their focal mechanisms. Tomographic studies in this area show the existence of low velocity in the upper mantle between the Betic Cordillera and the Alboran Sea (Serrano et al., 1998; Morales et al., 1999). This anomaly is located in the western part of the Alboran Sea and it extends to 100$\mathrm{km}$ depth, in the same region where the intermediate-depth events occur. 
The presence of the very deep earthquakes $(650 \mathrm{~km})$ under southern Spain is a further sign of the complexity of area B. Their focal mechanisms correspond to pressure and tension axes trending E-W and dipping about $45^{\circ}$. Tomographic studies of the area show the existence of an anomalous high velocity region extending in depth from $200 \mathrm{~km}$ to $700 \mathrm{~km}$ (BLANCO and SPAKMAN, 1993). Only a very small part of the area, a volume where the foci are located, is seismically active. The relation of this deep activity with that of intermediate depth is not clear, but results of focal mechanisms and tomographic studies suggest different origins for them. In both cases these may be related to subduction processes, more recent for intermediate-depth shocks and older for very deep activity.

\section{Acknowledgements}

The authors wish to thank the Instituto Geográfico Nacional (Madrid, Spain) for providing part of the data. The authors also appreciate valuable comments and discussion given by Dr. D. McKnight. This work has been supported in part by the Ministerio de Ciencia y Tecnología (Spain), project REN2000-0777-C02-01.

\section{REFERENCES}

Argus, D., Gordon, R., DeMets, C., and Stein, S. (1989), Closure of the Africa-Eurasia-North America Plate Motion Circuit and Tectonics of the Gloria Fault, J. Geophys. Res. 94, 5585-5602.

Blanco, M.J. and Spakman, W. (1993), The P Velocity Structure of the Mantle below the Iberian Peninsula: Evidence for Subducted Lithosphere below South Spain, Tectonophysics 221, 13-43.

Badal, J., Samardjeva, E., and Payo, G. (2000), Moment Magnitudes for Early (1923-1961) Instrumental Iberian Earthquakes, Bull. Seismol. Soc. Am 90,1161-1173.

Bezzeghoud, M. and Buforn, E. (1999). Source Parameters of the 1992 Melilla (Spain, $M_{w}=4.8$ ), 1994 Alhoceima (Morocco, $M_{w}=5.8$ ) and 1994 Mascara (Algeria, $M_{w}=5.7$ ) Earthquakes and Seismotectonic Implications, Bull. Seismol. Soc. Am. 89, 359-372.

Boletín de Sismos Próximos (1989), Instituto Geográfico Nacional, Madrid.

Borges, J.F., Fitas, A., Bezzeghoud, M., and Teves-Costa, P. (2001), Seismotectonics of Portugal and its adjacent area, Tectonophysics 337, 373-387.

Buforn, E., UdíAs, A., and ColombÁs, M.A. (1988a), Seismicity, Source Mechanisms and Seismotectonics of the Azores-Gibraltar Plate Boundary, Tectonophysics 152, 89-118.

Buforn, E., Udías, A., and Mézcua, J. (1988b), Seismicity and Focal Mechanisms in South Spain, Bull. Seismol. Soc. Am. 78, 2008-2224.

Buforn, E., Udías, A., and Madariaga, R. (1991a), Intermediate and Deep Earthquakes in Spain, Pure Appl. Geophys. 136, 375-393.

Buforn, E., Udías, A., Mézcua, J., and Madariaga, R. (1991b), A deep Earthquake under South Spain, 8 March 1990, Bull. Seismol. Soc. Am. 81, 1403-1407.

Buforn, E., Sanz de Galdeano, C., and Udías, A. (1995), Seismotectonics of the Ibero-Maghrebian Region, Tectonophysics 248, 247-261.

Buforn, E., Coca, P., UdíAs, A., and Lasa, C. (1997), Source Mechanism of Intermediate and Deep Earthquakes in Southern Spain, J. Seism. 1, 113-130.

Buforn, E. and SAnz de Galdeano, C. (2001), Focal Mechanism of Mula (Murcia, Spain) Earthquake of February 2, 1999, J. Seism. 5, 277-280. 
Calvert, A., Gomez, F., Seber, D., Barazangi, M., Jabour, N., Ibenbrahim, A., and Demnati (1997), An Integrate Geophysical Investigation of Recent Seismicity in the Al-Hoceima Region of North Morocco, Bull. Seismol. Soc. Am. 87, 637-651.

Chung, W. and Kanamori, H. (1976), Source Process and Tectonic Implications of the Spanish Deep-focus Earthquake of March 29, 1954, Phys. Earth and Plan. Int. 13, 85-96.

CocA, P. and Buforn, E. (1994), Mecanismos focales en el sur de España: periodo 1965-1985, Estudios Geológicos, Madrid 50, 1-2, 33-45.

CocA, P. (1999), Métodos para la inversión del tensor momento sísmico. Terremotos del Sur de España, Ph.D. Thesis, Universidad Complutense, Madrid, 300 pp.

DeMets, C., Gordon, R., Argus, D., and Stein, S. (1990), Current Plate Motions, Geophys. J. Int. 101, 425-478.

Docherty, C. and BAndA, E. (1995), Evidence of Eastward Migration of the Alboran Sea Based on Regional Subsidence Analysis: A Case for Basin Formation by Delamination of Subcrustal Lithosphere? Tectonics 14, 430-433.

Dziewonski, A. and Woodhouse, J. (1983), An Experiment in Systematic Study of Global Seismicity: Centroid Moment Tensor Solutions, J. Geophys. Res. 84, 3247-3271.

Eкström, G. and Dziewonski, A. (1988), Evidence in on Bias in Estimations of Earthquakes Size, Nature 332, 319-323.

Frohlich, C. and ApPerson, K.D. (1992), Earthquake Focal Mechanisms, Moment Tensors and Consistency of Seismic Activity near Plate Boundaries, Tectonics 11, 279-296.

Grimison, N. and Cheng, W. (1986), The Azores-Gibraltar Plate Boundary: Focal Mechanisms, Depths of Earthquakes and their Tectonic Implications, J. Geophys. Res. 91, 2029-2047.

HatzFeld, D. (1978), Etude sismotectonique de la zone de collision Ibero-Maghrébine, Ph.D. Thesis, Grenoble (France), $281 \mathrm{pp}$.

Hayward, N., Watts, A.B., Westbrook, G.K. and Collier, J.S. (1999), A Seismic Reflection and GLORIA Study of Compressional Deformation in the Gorringe Bank Region, Eastern North Atlantic, Geophys. J. Int. 138, 831-850.

Houseman, G. (1996), From Mountains to Basin, Nature 379, 771-772.

Jimenez-Munt, I., Bird, P., and Fernandez, M. (2001), Thin-shell Modeling of Neotectonics in the Azores-Gibraltar Region, Geophys. Res. Lett. 28, 6, 1083-1086.

Lammali, K., Bezzeghoud, M., Oussadou, F., Dimitrov, D., and Benhallou, H. (1997), Postseismic Deformation at El Asnam (Algeria) in the Seismotectonic Context of Northwestern Algeria, Geophys. J. Int. 129, 597-612.

Lonergan, L. and White, N. (1997), Origin of the Betic-Rif Mountain Belt, Tectonics 16, 3, 504-522.

McKenzIE, D. (1972), Active Tectonics of the Mediterranean Region, Geophys. J. R. Astron. Soc. 30, 109185.

Medina, F. and Cherkaoui, T.E. (1992). Mechanismes au foyer des seismes de Maroc et des régions voisines (1959-1986), Conséquences tectoniques, Eclogae Geol. Helv. 85, 433-457.

Mézcua, J. and Martínez Solares, J.M. (1983), Sismicidad del área Ibero-Mogrebi, Instituto Geográfico Nacional Madrid.

Mézcua, J. and Rueda, J. (1997), Seismological Evidence for a Delamination Process in the Lithosphere under Alborán Sea, Geophys. J. Int. 129, F1-F8.

Michard, A., Chalouan, A., Feinberg, H., Goffé, B., and Montigny, R. (2002), How Does the Alpine Belt End between Spain and Morocco? Bull. Soc. Geol. France 173, 3-15.

Mokrane, A., Ait Messaoud, A., Sebai, A., Menia, N., Ayadi, A., Bezzeghoud, M. (1994), Les séismes en Algérie de 1365 à 1992, Bezzeghoud, M. and Benhallou, H. (eds). Publication du CRAAG, AlgerBouzaréah, 277 pp.

Morales, J., Serrano, I., Jabaloy, A., Galindo-Zaldivar, J., Zhao, D., Torcal, F., Vidal, F., and Gonzalez-Lodeiro, F. (1999), Active Continental Subduction beneath the Betic Cordillera and the Alboran Sea, Geology 27, 735-738.

Morel, J. and Meghraoui, M. (1996), Gorringe-Alboran-Tell Tectonic Zone: A Transpressio System along the Africa-Eurasia Plate Boundary, Geology 24, 755-758.

Morley, C. (1993), Discussion of the Origins of Hinterland Basins to the Rif-Betic Cordillera and Carpathians, Tectonophysics 226, 359-376. 
Munuera, J.M. (1963), Datos básicos para un estudio de sismicidad en la región de la Península Ibérica. Mem. Inst. Geog. Cat., Madrid, 32, 93 pp.

MuÑoz, D. and UdíAs, A. (1988), Evaluation of damage and source parameters of the Málaga earthquake of 9 October 1680. In W.H.K. Lee, H. Meyer and K. Shimazaki, (eds), Historical Seismograms and Earthquakes of the World (Academic Press, San Diego 1988), pp. 208-221.

Negredo, A., Bird, P., Sanz de Galdeano, C., and Buforn, E. (2002), Neotectonic Modeling of the Ibero-Maghrebian Region, J. Geophys. Res., in press.

Platt, J.P. and Vissers, R. (1989), Extensional Collapse of Thickened Continental Lithosphere: A Working Hypothesis for the Alboran Sea and Gibraltar Arc, Geology 17, 540-543.

Rueda, J., Mézcua, J., and Sanchez Ramos, M. (1996), La serie sísmica de Adra (Almeria) de 1993-1994 y sus principales consecuencias sismotectónicas, Avances en Geofísica y Geodesia, Instituto Geográfico Nacional, Madrid, 91-98.

Seber, D., Barazangi, M., Ibenbrahim, and Demnati, A. (1996), Geophysical Evidence for Lithospheric Delamination beneath the Alboran Sea and Rif-Betic Mountains, Nature 379, 785-790.

Serrano, I., Morales, J., Zhao, D., Torcal, F., and Vidal, F. (1998), P-wave Tomographic Images in the Central Betics-Alboran Sea (South Spain) Using Local Earthquakes: Contribution for a Continental Collision, Geophys. Res. Lett. 25, 4031-4034.

Tejedor, J.M. and García , O. (1993), Funciones de transferencia de las estaciones de la red Sísmica Nacional. Instituto Geográfico Nacional, Madrid, 82 pp.

Torné, M., Fernandez, M., Comas, M.C., and Soto, J.I. (2000), Lithospheric Structure beneath the Alboran Basin: Results from 3D Gravity Modeling and Tectonic Revelance, J. Geophys. Res. 105, 32093228.

Udías, A., López Arroyo, A., and Mézcua, J. (1976), Seismotectonics of the Azores-Alboran Region, Tectonophysics 31, 259-289.

Yelles-Chaouche, A.K., Djellit, H., Beldjoudi, H., Bezzeghoud, M. and Buforn, E, The Ain Temouchent Earthquake of December 22th, 1999, Pure Appl. Geophys., this issue.

ZECK, H. (1996), Betic-Rif Orogeny: subduction of Mesozoic Tethys under E-ward Drifting Iberia, Slab Detachment Shortly before 22 Ma and Subsequent Uplift and Extensional Tectonics, Tectonophysics 254, $1-16$.

(Received May 3, 2002, revised November 5, 2002, accepted December 12, 2002)

To access this journal online:
(20) http://www.birkhauser.ch




\section{Annex 1}

Focal mechanisms of earthquakes studied in this paper obtained from polarities of P-waves. At top date of the shock, black circles correspond to compressions and white circles to dilatations. $\mathrm{T}$ and $\mathrm{P}$ indicate the tension and pressure axis.

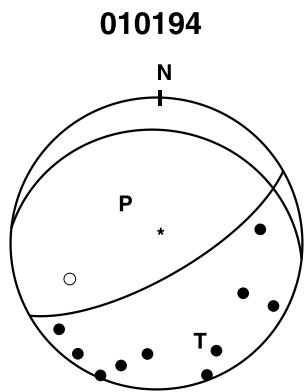

281195

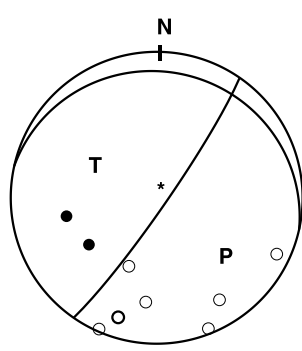

180397

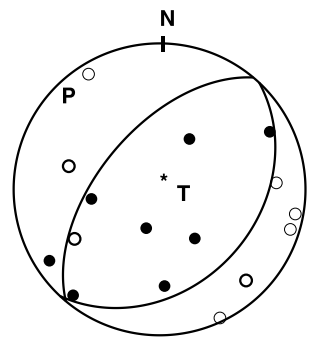

170395

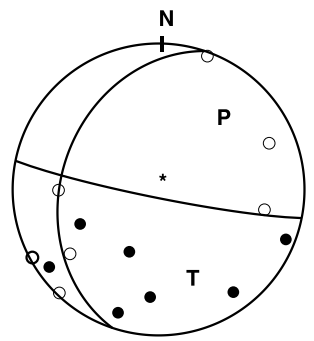

220696

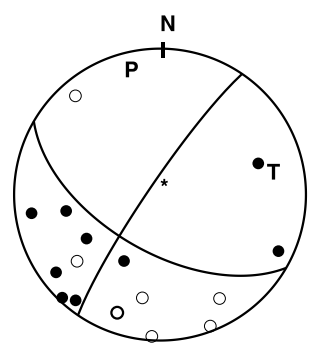

200897

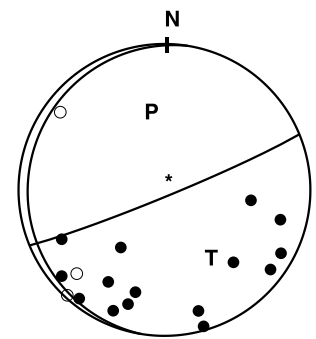

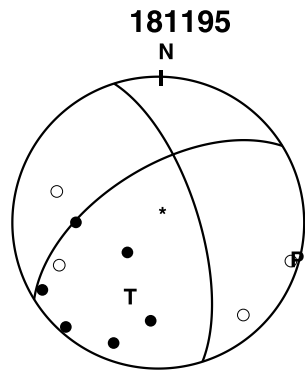

271396

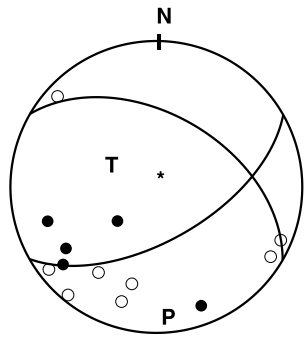


Annex 2

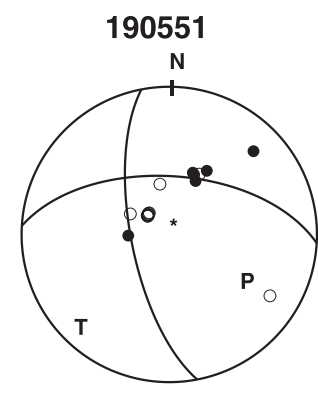

071190
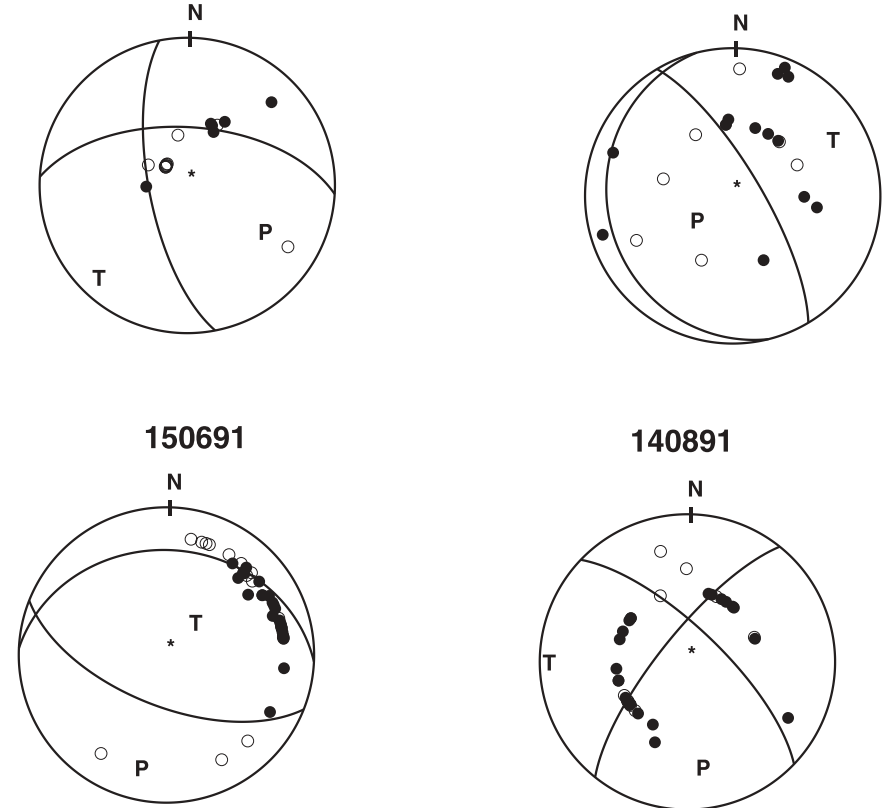

140891
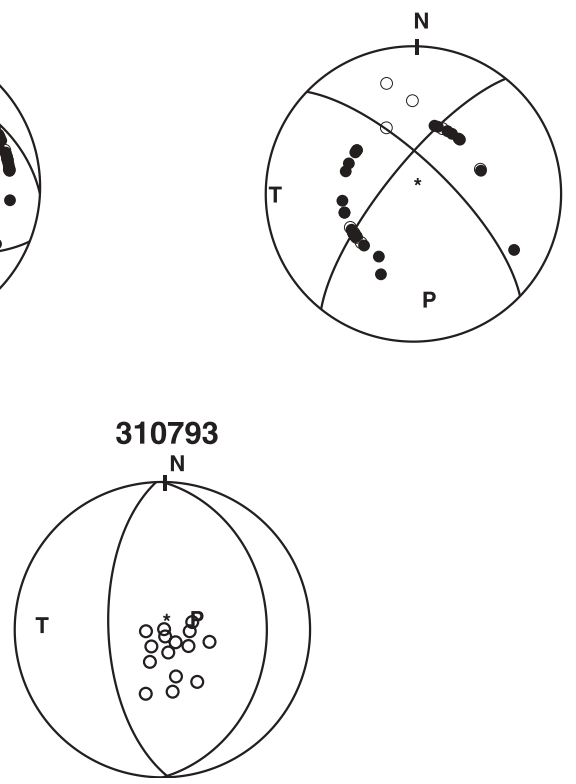